\title{
Determination of the $\mathrm{pK}_{\mathrm{a}}$ Values of some Biologically Active and Inactive Hydroxyquinones
}

\author{
Tadeusz Ossowski, ${ }^{a}$ Marília O. F. Goulart, ${ }^{*}, b$ Fabiane C. de Abreu, ${ }^{b}$ Antônio Euzébio G. Sant'Ana, ${ }^{b}$ Paulo \\ Rogério B. Miranda, ${ }^{b}$ Cicero de Oliveira Costa ${ }^{b}$ Adam Liwo, ${ }^{a}$ Piotr Falkowski ${ }^{a}$ and Dorota Zarzeczanska ${ }^{a}$
}

${ }^{a}$ Faculty of Chemistry, University of Gdansk, Sobieskiego 18, 80-952, Poland

${ }^{b}$ Instituto de Química e Biotecnologia, Universidade Federal de Alagoas, Tabuleiro do Martins, 57072-970 Maceió-AL, Brazil

\begin{abstract}
As constantes de dissociação aparentes $\left(\mathrm{pK}_{\mathrm{a}}\right)$ de quatro 2-hidroxinaftoquinonas, diferentemente substituídas em C-3, foram determinadas em meio aquoso-etanólico (1:1, v/v), utilizando titulações pH-métricas e espectrofotométricas. O isolapachol $\left(\mathrm{pK}_{\mathrm{a}}<6\right)$ mostrou ser mais ácido que seu análogo natural, o lapachol, $\left(\mathrm{pK}_{\mathrm{a}}>6\right)$. Os derivados 3-metilaminados apresentam dois valores de $\mathrm{pK}_{\mathrm{a}}$, um relacionado ao grupo enólico e o outro ao sal de amônio, e são zwitteriônicos, em larga extensão, em pH fisiológico. As possíveis conseqüências desses parâmetros frente a suas atividades biológicas são discutidas.
\end{abstract}

The apparent dissociation constants $\left(\mathrm{pK}_{\mathrm{a}}\right)$ of four 2-hydroxynaphthoquinones, differently substituted at C-3, were determined in water:ethanol $(1: 1, \mathrm{v} / \mathrm{v})$ solutions by $\mathrm{pH}$-metric and hybrid $\mathrm{pH}$-metric/UV titration methods. Isolapachol $\left(\mathrm{pK}_{\mathrm{a}}<6\right)$ was more acidic than lapachol $\left(\mathrm{pK}_{\mathrm{a}}>6\right)$. Two $\mathrm{pK}_{\mathrm{a}}$ values were determined for each of the methylamino-derivatives investigated, the first relating to the enol function and the second to the ammonium salt. It was determined that under physiological $\mathrm{pH}$, these derivatives would be to a large extension, zwitterionic. The possible effects of the measured parameters on the biological activities of the studied compounds are discussed.

Keywords: acid dissociation constants, hydroxyquinones, $\mathrm{pH}$-metric titration, hybrid $\mathrm{pH}-$ metric/UV titration, molluscicidal activity

\section{Introduction}

Lapachol (1) possesses anti-tumour, antibiotic, antimalarial, anti-inflammatory and anti-ulcer properties, ${ }^{1}$ whilst both $\mathbf{1}^{2-6}$ and isolapachol (2) ${ }^{4,6}$ exhibit significant activities against the etiological agents of a number of tropical diseases. Additionally, the 2-hydroxy-1,4-naphthoquinones $\mathbf{1}$ and $\mathbf{2}$ are potent molluscicides (Table 1) with activities against both mature adults and egg masses of Biomphalaria glabrata, ${ }^{2,3,7}$ the intermediate host of the causative agent of schistosomiasis (Schistosoma mansoni) ${ }^{8,9}$ In contrast, a group of fourteen 2-hydroxy-3-methylnitrogenated-1,4naphthoquinones were inactive in molluscicidal assays, ${ }^{7}$ and the representative compounds $\mathbf{3}$ and $\mathbf{4}$ showed no activity against Artemia salina ${ }^{10}$ an organism used for cytotoxicity screening. ${ }^{4} 11$

*e-mail: mofg@ufal.br; marilia.goulart@pq.cnpq.br
It has been suggested that the mechanism of molluscicidal action of the 2-hydroxy-1,4-naphthoquinones may be related to their redox parameters, ${ }^{7}$ which in turn are strongly associated with their acid-base properties. ${ }^{12}$ However, it is well-established that biological activity towards a live host is a complex outcome that is not usually dominated by one parameter. Generally, various physico-chemical properties impact on the pharmacokinetic and metabolic fate of a biologically active compound and, hence, a thorough understanding of such characteristics is crucial in understanding the mode of action. ${ }^{13}$ The most important of the parameters are lipophilicity, solubility, permeability and apparent acid dissociation constants $\left(\mathrm{pK}_{\mathrm{a}}\right)$, since these determine the absorption and bioavailability of the molecule, as well as its specific interactions with enzymes. ${ }^{13-16}$

Of particular interest is the role of $\mathrm{pK}_{\mathrm{a}}$ on absorption, since this is often related to its effect on lipophilicity and solubility. ${ }^{14}$ In order to measure $\mathrm{pK}_{\mathrm{a}}$ values, it is necessary 
to expose the analyte to an environment of changing $\mathrm{pH}$ and to monitor a specific property that varies as a function of the ionisation state of the molecule. Several methods for conducting such an analysis are available including the rapid techniques of $\mathrm{pH}$-metric titration and hybrid $\mathrm{pH}$ metric/UV titration. The $\mathrm{pH}$-metric titration is an important reference method because it can be used to measure $\mathrm{pK}_{\mathrm{a}}$ values between 2 and 12 in the presence or absence of a chromophore, provided that the sample can be dissolved in water or water and a co-solvent over the $\mathrm{pH}$ range of interest. In this method, acid-base titration of a sample solution is monitored with a glass $\mathrm{pH}$ electrode, and $\mathrm{pK}_{\mathrm{a}}$ is calculated from the change in shape of the titration curve in comparison with that of a blank titration carried out in the absence of the sample. ${ }^{14}$ The hybrid method, also known as spectrophotometric $\mathrm{pK}_{\mathrm{a}}$ determination, is an attractive alternative provided that the sample is soluble in water to the extent of $10^{-6} \mathrm{~mol} \mathrm{~L}^{-1}$ and also contains chromophore(s) in proximity to the ionisation centre(s) such that the protonated and deprotonated forms exhibit sufficient spectral dissimilarities. ${ }^{17}$ In this method, an acid-base titration is conducted across a $\mathrm{pH}$ range that includes the $\mathrm{pK}_{\mathrm{a}}$, and UV spectra are recorded for each $\mathrm{pH}$ value. ${ }^{14}$

With the aim of elucidating the spectra of biological activities of the 2-hydroxy-3-methylamino-1,4-naphthoquinones, we have determined the $\mathrm{pK}_{\mathrm{a}}$ values of representative compounds $\mathbf{3}$ and $\mathbf{4}$, together with those of the active 2-hydroxy1,4-naphthoquinones $\mathbf{1}$ and $\mathbf{2}$, and have evaluated these data in terms of the known bioactivities of the respective analytes. The $\mathrm{pK}_{\mathrm{a}}$ values were determined in water: ethanol $(1: 1, \mathrm{v} / \mathrm{v})$ solutions, in order to allow the complete dissolution of the samples over the entire $\mathrm{pH}$ range, using both the $\mathrm{pH}$-metric and hybrid $\mathrm{pH}-\mathrm{metric} / \mathrm{UV}$ titration methods.

\section{Experimental}

\section{Chemicals}

The natural product lapachol (1) [2-hydroxy-3-(3-methyl2-butenyl)-1,4-naphthoquinone] was kindly supplied by Prof. Antonio Ventura Pinto (Núcleo de Pesquisas de Produtos Naturais, Universidade Federal do Rio de Janeiro, Brazil). Isolapachol (2) [2-hydroxy-3-(3-methyl-1-butenyl)-1,4naphthoquinone] was synthesized by reaction of lawsone (2-hydroxy-1,4-naphthoquinone) and isovaleraldehyde (Aldrich) in acidic medium. ${ }^{18}$ Quinones 3 (2-hydroxy-3methyl-N-morpholine-1,4-naphthoquinone) and 4 (2-hydroxy3-methyl-N-hexyl-1,4-naphthoquinone) were synthesized by the Mannich reaction ${ }^{19}$ using one mole ratios of lawsone, formalin and, respectively, $\mathrm{N}$-morpholine or cyclohexylamine,

Table 1. Structures, first wave reduction potentials and biological activities of lapachol (1), isolapachol (2), 2-hydroxy-3-methyl-N-morpholine-1,4naphthoquinone (3) and 2-hydroxy-3-methyl-N-hexyl-1,4-naphthoquinone (4)

\begin{tabular}{|c|c|c|}
\hline Structures & First wave reduction potential ${ }^{a}$ & Biological activities / ppm \\
\hline \multirow{6}{*}{1} & \multirow{6}{*}{$-0.666 \mathrm{~V}$} & $\mathrm{LD}_{90}(\text { Biomphalaria glabrata }, \text { adults })^{7}=6.18$ \\
\hline & & $\mathrm{LD}_{90}(\text { B. } \text { glabrata }, \text { egg masses })^{2,3,7}=0.190$ \\
\hline & & 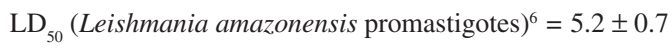 \\
\hline & & $\mathrm{LD}_{50}(\text { L. braziliensis promastigotes })^{6}=11.9 \pm 6.9$ \\
\hline & & $\mathrm{LD}_{50}(\text { Artemia salina })^{10}=12.75$ \\
\hline & & $\mathrm{LD}_{90}(\text { A. salina })^{4}=176.30($ as potassium salt $)$ \\
\hline \multirow{6}{*}{2} & \multirow{6}{*}{$-0.642 \mathrm{~V}$} & $\mathrm{LD}_{90}(\text { B. } \text { glabrata }, \text { adults })^{7}=4.30$ \\
\hline & & $\mathrm{LD}_{90}(\text { B. glabrata }, \text { egg masses })^{2,3,7}=0.092$ \\
\hline & & $\mathrm{LD}_{50}(\text { L. amazonensis promastigotes })^{6}=4.4 \pm 2.9$ \\
\hline & & $\mathrm{LD}_{50}(\text { L. braziliensis promastigotes })^{6}=9.3 \pm 2.7$ \\
\hline & & $\mathrm{LD}_{90}(\text { A. salina })^{11}=30.43$ \\
\hline & & $\mathrm{LD}_{90}(\text { Artemia salina })^{4}=1.85($ as potassium salt $)$ \\
\hline \multirow{2}{*}{3} & \multirow{2}{*}{$-0.780 \mathrm{~V}$} & B. glabrata, adults and egg masses: inactive ${ }^{7}$ \\
\hline & & A. salina: inactive ${ }^{11}$ \\
\hline \multirow{2}{*}{4} & \multirow{2}{*}{$-0.870 \mathrm{~V}$} & B. glabrata, adults and egg masses: inactive ${ }^{7}$ \\
\hline & & A. salina: inactive ${ }^{11}$ \\
\hline
\end{tabular}

${ }^{a} \mathrm{EpIc}(\mathrm{GCE})\left(\mathrm{DMF}+\mathrm{TBAP} 0.1 \mathrm{~mol} \mathrm{~L}^{-1}\right)$.
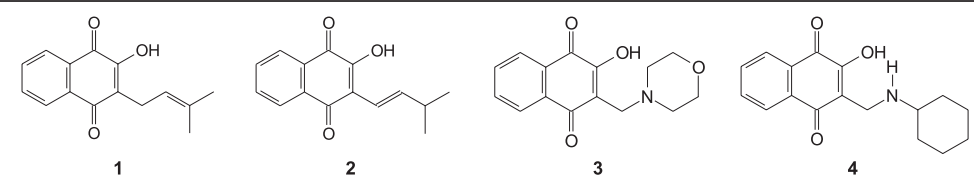
in alcohol solution. ${ }^{19}$ Compounds $\mathbf{3}$ and $\mathbf{4}$ were kindly supplied by Prof. Antonio Ventura Pinto. All of the compounds investigated showed analytical and spectral (IR, NMR) data in full accord with the indicated structures.

2-Hydroxy-3-methyl-N-morpholine-1,4-naphthoquinone (3) Red needles; mp 185-186 ${ }^{\circ} \mathrm{C} ;{ }^{19}{ }^{1} \mathrm{H}-\mathrm{NMR}(300 \mathrm{MHz}$, DMSO-d ${ }_{6}$ : $\delta 8.0-7.6(\mathrm{~m}, 4 \mathrm{H}, \mathrm{ArH}), 7.3$ (bs, $1 \mathrm{H}, \mathrm{OH}$, disappeared after addition of $\left.\mathrm{D}_{2} \mathrm{O}\right), 3.91\left(\mathrm{bs}, 4 \mathrm{H},-\mathrm{NC}_{2} \mathrm{CH}_{2} \mathrm{O}\right.$ ), 3.83 (s, 2H, $\left.-\mathrm{CCH}_{2} \mathrm{~N}\right), 3.30$ (bs, $4 \mathrm{H},-\mathrm{NCH}_{2} \underline{\mathrm{C}}_{2} \mathrm{O}$ ); ${ }^{13} \mathrm{C}$ NMR (75 MHz, DMSO-d $): \delta 183.3(\mathrm{C}=\mathrm{O}), 182.2$ $(\mathrm{C}=\mathrm{O}), 163.8\left(\mathrm{C}_{0}\right), 133.7(\mathrm{CH}), 133.2\left(\mathrm{C}_{0}\right), 131.8(\mathrm{CH})$, $130.7\left(\mathrm{C}_{0}\right), 125.4(\mathrm{CH}), 125.2(\mathrm{CH}), 121.3\left(\mathrm{C}_{0}\right), 63.5$ $\left(\mathrm{CH}_{2} \mathrm{O}\right), 43.2\left(\mathrm{CH}_{2} \mathrm{~N}\right), 17.6\left(\mathrm{CCH}_{2} \mathrm{~N}\right)$.

\section{2-Hydroxy-3-methyl-N-hexyl-1,4-naphthoquinone (4)}

Orange needles; mp 185-190 ${ }^{\circ} \mathrm{C} .{ }^{19}{ }^{1} \mathrm{H}-\mathrm{NMR}(400 \mathrm{MHz}$, $\left.\mathrm{CDCl}_{3}\right): \delta 7.79(\mathrm{~d}, 1 \mathrm{H}, \mathrm{ArH}), 7.43(\mathrm{t}, 1 \mathrm{H}, \mathrm{ArH}), 7.41(\mathrm{~d}$, $1 \mathrm{H}, \mathrm{ArH}), 7.18$ (t, 1H, ArH), 4.04 (s, 2H), 3.2-3.0 (m, 1H, -NCH), 2.3-2.2 (m, 2H), 2.0-1.85 (m, 2H), 1.82-1.78 (m, $1 \mathrm{H}$, disappeared after addition of $\left.\mathrm{D}_{2} \mathrm{O}\right), 1.78-1.60(\mathrm{~m}, 3 \mathrm{H})$, 1.50-1.28 (m, 3H): ${ }^{13} \mathrm{C}-\mathrm{NMR}\left(100 \mathrm{MHz}, \mathrm{CDCl}_{3}\right): \delta 184.6$ $(\mathrm{C}=\mathrm{O}), 182.8(\mathrm{C}=\mathrm{O}), 171.4\left(\mathrm{C}_{0}\right), 133.9\left(\mathrm{C}_{0}\right), 133.7(\mathrm{CH})$, $131.1(\mathrm{CH}), 131.0\left(\mathrm{C}_{0}\right), 126.0(\mathrm{CH}), 125.1(\mathrm{CH}), 108.9$ $\left(\mathrm{C}_{0}\right), 56.5(\mathrm{CH}), 40.0\left(\mathrm{CH}_{2} \mathrm{~N}\right), 29.5\left(\mathrm{CH}_{2}\right), 24.9\left(\mathrm{CH}_{2}\right)$, $24.2\left(\mathrm{CH}_{2}\right)$.

\section{Potentiometric titrations}

Potentiometric titrations were carried out using a Cerko Lab System microtitration unit, consisting of a microprocessor-controlled dosing unit, a precise 18-bit $\mathrm{pH}$-meter and a host PC, together with a Mettler Toledo InLab $423 \mathrm{pH}$ microelectrode. For measurements in water solutions, the $\mathrm{pH}$ electrode was calibrated against at least five buffers as recommended by IUPAC..$^{20}$ For the water: ethanol system, the electrode was calibrated using potassium hydrogen phthalate as described in the reference value $\mathrm{pH}$ standard (RVS) method previously published..$^{21,22}$ In a typical experiment, an aliquot $(2 \mathrm{~mL})$ of a solution of quinone and perchloric acid ( $\left.c a .5 \times 10^{-4} \mathrm{~mol} \mathrm{~L}^{-1}\right)$ was titrated against sodium hydroxide $\left(\mathrm{ca} .10^{-2} \mathrm{~mol} \mathrm{~L}^{-1}\right)$. The resolution of the titration step was $<0.001 \mathrm{~mL}$ (using a $0.5 \mathrm{~mL}$ Hamilton syringe), and the resolution of the voltage measurement was $<0.1 \mathrm{mV}$. Equilibrium constants were calculated with the aid of the STOICHIO program, which employs a non-linear least-squares Gauss-Newton-Marquardt algorithm. ${ }^{23}$

\section{Spectrophotometric titrations}

Compounds 1-4 were dissolved in water:ethanol (1:1), acidified to low $\mathrm{pH}$ values $(\sim 3)$ with $0.02 \mathrm{~mol} \mathrm{~L}^{-1}$ hydrochloric acid, and aliquots (typically $1.5 \mathrm{~mL}$ ) titrated against sodium hydroxide $\left(8.944 \times 10^{-3} \mathrm{~mol} \mathrm{~L}^{-1}\right)$ in steps of $0.002 \mathrm{~mL}$ or less to a final $\mathrm{pH}$ of $12 .{ }^{24}$ Initially, sample solutions contained the protonated hydroxyquinones at concentrations of $c a .5 \times 10^{-4} \mathrm{~mol} \mathrm{~L}^{-1}$, the exact values being $c_{1}=5.32 \times 10^{-4} \mathrm{~mol} \mathrm{~L}^{-1}, c_{2}=3.92 \times 10^{-4} \mathrm{~mol} \mathrm{~L}^{-1}$, $c_{3}=5.39 \times 10^{-4} \mathrm{~mol} \mathrm{~L}^{-1}$ and $c_{4}=7.43 \times 10^{-4} \mathrm{~mol} \mathrm{~L}^{-1}$. Samples (typically $1.5 \mathrm{~mL}$ ) were titrated in steps of $0.002 \mathrm{~mL}$ or less with sodium hydroxide $\left(8.944 \times 10^{-3} \mathrm{~mol} \mathrm{~L}^{-1}\right)$ to a final $\mathrm{pH}$ of $12 .{ }^{24}$ The UV-Vis spectra were recorded, after the addition of gradually increasing amounts of base, using a Perkin Elmer Lambda 40 spectrophotometer and a $1 \mathrm{~cm}$ quartz cuvette. All measurements were carried out at 298.1 K. Plots of absorption at different wavelengths versus apparent $\mathrm{pH}$ values of sample the solution generated sigmoid curves. The $\mathrm{pK}_{\mathrm{a}}$ constants were determined for samples 1-4 on the basis of Henderson-Hasselbach equations. ${ }^{25,26}$

\section{Results and Discussion}

Under acidic conditions, the spectrum in the range 300-600 nm of a water:ethanol (1:1) solution of lapachol (1) showed two absorption bands with maxima at 337 and $390 \mathrm{~nm}$, whereas in alkaline solution the spectrum exhibited a single absorption band with its maximum located at 490 nm (Figure 1A). The same features could be observed upon titration of an acidic solution of $\mathbf{1}$ with sodium hydroxide (Figure 1B), and the changes in UV absorbance monitored at 337, 370, 390 and $490 \mathrm{~nm}$ throughout the spectrophotometric titration showed a similar pattern (Figure 2). A pK value for 1 of $6.15 \pm 0.01$ was calculated at a wavelength of $490 \mathrm{~nm}$ on the basis of Henderson-Hasselbach equations.

Potentiometric titration of (1) performed in a water:ethanol (1:1) solution containing perchloric acid showed a pattern characteristic of a mixture of more and less strong acids. Two steps were observed in the potentiometric curve (Figure 3 ), the first relating to the neutralization of perchloric acid and the second to the formation of the enolate from the enol. From the potentiometric data, the equilibrium constant for $\mathbf{1}$ was calculated on the basis of the Gauss-Newton-Marquardt algorithm ${ }^{23}$ and gave a value for $\mathrm{pK}_{\mathrm{a}}$ of $6.31 \pm 0.03$. The data obtained for $\mathbf{1}$ from the spectroscopic and potentiometric titrations are in good agreement and support the model of the equilibrium in water:ethanol solution.

The $\mathrm{pH}$-dependent changes in the UV spectrum of isolapachol (2) were comparable with those observed for $\mathbf{1}$ monitored under similar conditions. At pH 3.2, compound 2 exhibited absorptions at $337 \mathrm{~nm}$ (shoulder I) and $445 \mathrm{~nm}$ (band II), but in alkaline solution a bathochromic shift was observed and a broad band at $540 \mathrm{~nm}$ appeared (Figure $4 \mathrm{~A})$. The same features were displayed upon titration of 

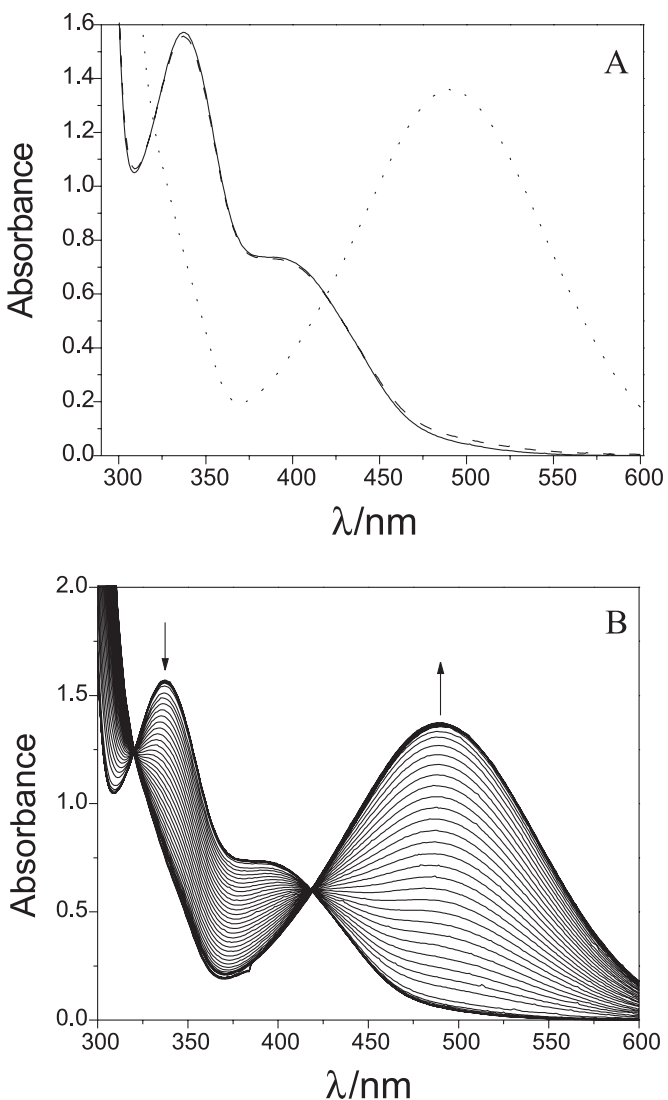

Figure 1. A) The absorption spectra of a water:ethanol (1:1) solution of $\mathbf{1}$ recorded at $\mathrm{pH}$ values $3.15(-), 4.30$ (--) and 10.90 (....). B) UV-Vis spectrophotometric titration of a water:ethanol (1:1) solution of 1 . The arrows indicate the change in absorbance ( $\downarrow$ decrease; $\uparrow$ increase) upon addition of base. an acidic solution of $\mathbf{2}$ with sodium hydroxide (Figure 4B). Slight alterations in the spectrum of $\mathbf{2}$ could be observed between $\mathrm{pH} 3.2$ and 4.7, with an increase in absorbance at shoulder I and a concomitant decrease of band II. This could be related to possible tautomerism and protonation of the double bond at lower $\mathrm{pH}$ values (Figure 5), a phenomenon that did not affect the $\mathrm{pK}_{\mathrm{a}}$. A value of $5.75 \pm 0.01$ for the $\mathrm{pK}_{\mathrm{a}}$ of 2 was calculated at a wavelength of $540 \mathrm{~nm}$ (Figure 6) on the basis of Henderson-Hasselbach equations. ${ }^{25,26}$ The $\mathrm{pK}_{\mathrm{a}}$ of $\mathbf{2}$ was also determined by the potentiometric method as described for compound $\mathbf{1}$, and a value of $5.98 \pm 0.03$ was obtained (data not shown).

With respect to the 2-hydroxy-3-methylaminonaphthoquinones $\mathbf{3}$ and $\mathbf{4}$, more complex features were, as expected, observed in the plots of UV absorption versus $\mathrm{pH}$. In the case of compound $\mathbf{3}$, which carries a tertiary cyclic amine (methylmorpholine), the UV-Vis spectrum measured at $\mathrm{pH}$ 1.2 exhibited a maximum absorbance at $330 \mathrm{~nm}$ (Figure 7A). Upon the addition of base, an absorbance maximum was observed at $323 \mathrm{~nm}$ and a second broad band appeared at $452 \mathrm{~nm}$, the latter undergoing a bathochromic shift towards $470 \mathrm{~nm}$ as the $\mathrm{pH}$ approached 12 (Figure 7B). After $3 \mathrm{~h}$ under alkaline conditions, this absorbance pattern changed slightly indicating a certain degree of instability of the quinone. The changes in UV absorbance of $\mathbf{3}$ were monitored at 330, 366, 440 and $470 \mathrm{~nm}$ throughout the spectrophotometric titration (Figure 8), and the plots obtained indicated the presence of two points of inflection. Although
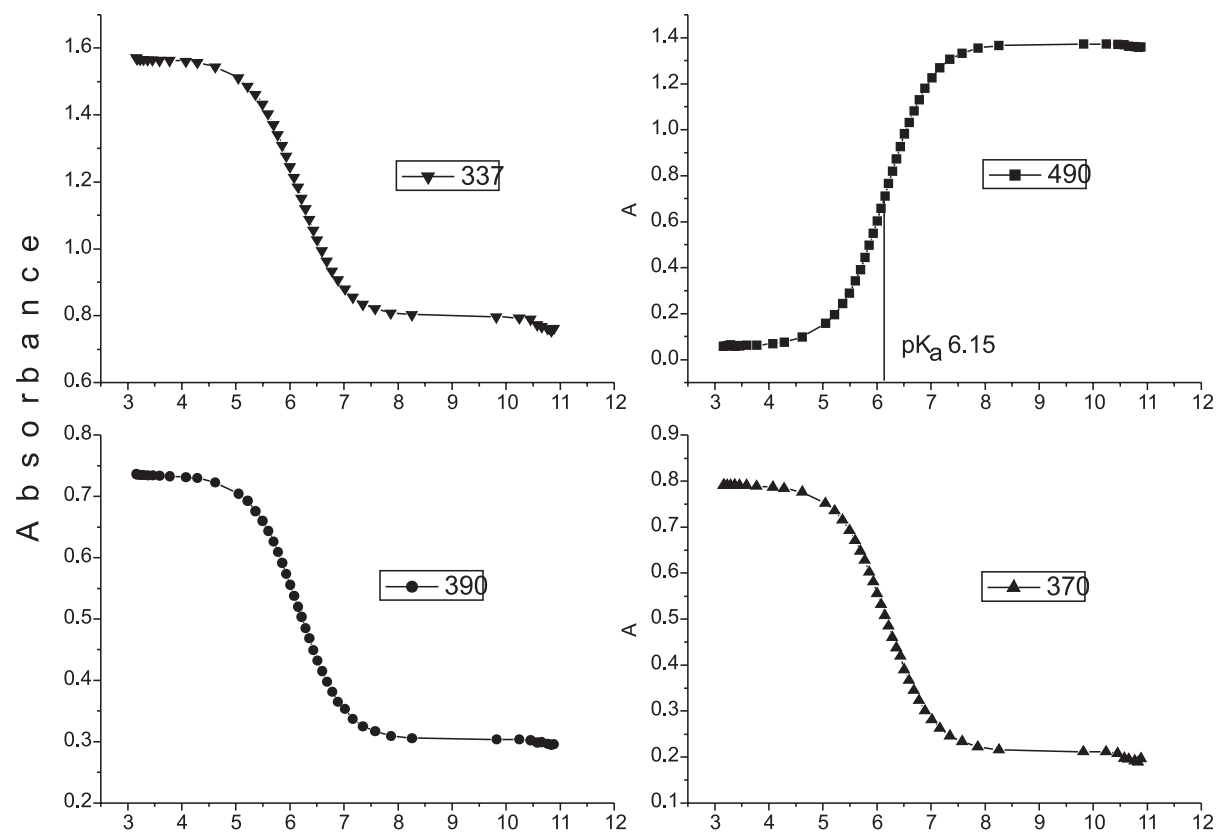

$\mathrm{pH}$

Figure 2. Absorption at different wavelengths of a water:ethanol (1:1) solution of $\mathbf{1}$ as a function of pH. The point of inflection on the $490 \mathrm{~nm}$ plot gave a $\mathrm{pK}_{\mathrm{a}}$ value of 6.15 . 


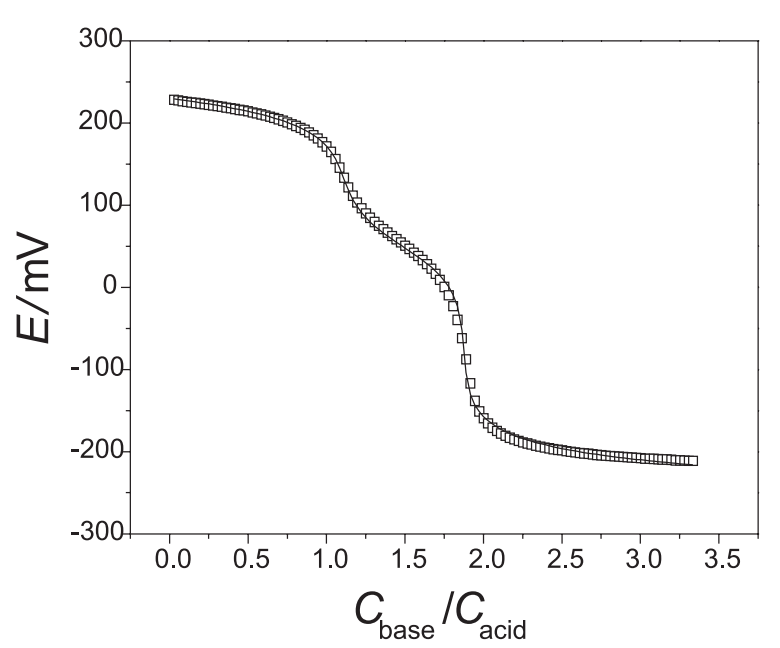

Figure 3. Potentiometric titration of a water:ethanol (1:1) solution of $\mathbf{1}$. $C_{1}=5.530 \times 10^{-4} \mathrm{~mol} \mathrm{~L}^{-1}, C_{\text {acid }} 7.460 \times 10^{-4} \mathrm{~mol} \mathrm{~L}^{-1}, C_{\text {base }}=8.944 \times 10^{-3}$ mol L $\mathrm{L}^{-1} ; \mathrm{pK}_{\mathrm{a}}$ calculated as $6.31 \pm 0.0277$.
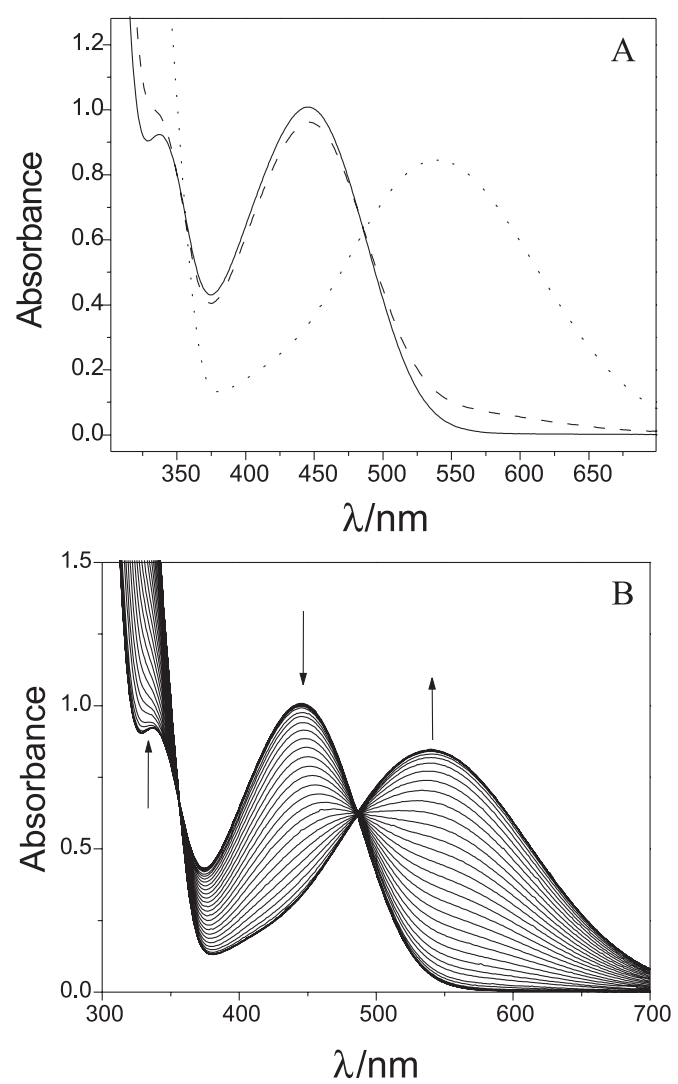

Figure 4. A) Absorption spectra of a water:ethanol (1:1) solution of 2 recorded at $\mathrm{pH}$ values $3.20(-), 4.70(--)$ and $10.80(\ldots$.$) . B) UV-Vis$ spectrophotometric titration of a water:ethanol (1:1) solution of $\mathbf{2}$. The arrows indicate the change in absorbance ( $\downarrow$ decrease; $\uparrow$ increase) upon addition of base.

it was not possible to obtain a complete curve at lower $\mathrm{pH}$ values, the first ionisation value could be estimated as $<3.5$<smiles>C#[P+]C(C)/C=C/C1=C(O)C(=O)c2ccccc2C1=O</smiles>

Figure 5. Acid-base equilibrium for isolapachol (2).

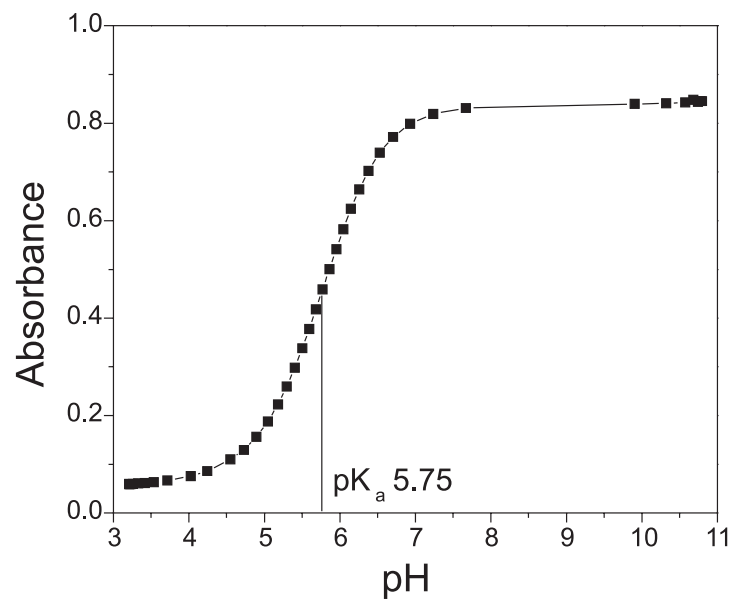

Figure 6. Absorption at $490 \mathrm{~nm}$ of a water:ethanol (1:1) solution of $\mathbf{2}$ as a function of $\mathrm{pH}$. The point of inflection gave a $\mathrm{pK}$ value of 5.75.

at a wavelength of $470 \mathrm{~nm}$. The second ionisation constant, obtained at higher $\mathrm{pH}$, could be calculated precisely from the second inflection point at $470 \mathrm{~nm}$ and gave a $\mathrm{pK}_{\mathrm{a} 2}$ for compound 3 of $8.59 \pm 0.02$.

The spectroscopic behaviour of $\mathbf{4}$ resembled that of compound $\mathbf{3}$ and revealed the presence of two $\mathrm{pK}_{\mathrm{a}}$ values. For compound 4, however, the absorption at $450 \mathrm{~nm}$ increased upon base addition and attained an almost constant value in the $\mathrm{pH}$ range 4-9.5 (Figure 9). Moreover, a further increase in $\mathrm{pH}$ resulted in an increase in absorption, such that the data only allowed the conclusions that $\mathrm{pK}_{\mathrm{a} 1}$ could be lower than 3.50 and that $\mathrm{pK}_{\mathrm{a} 2}$ could be higher than 10 .

More precise information was obtained from potentiometric investigations of water: ethanol solutions of compounds 3 and 4 . In the potentiometric curve of 3 (Figure 10), only one inflection point was visible. However, after fitting of the data using the STOICHIO program ${ }^{23,24}$ the existence of two equilibria became apparent, one with $\mathrm{pK}_{\mathrm{a} 1}(\mathrm{OH})$ at $3.36 \pm 0.13$ and the second with $\mathrm{pK}_{\mathrm{a} 2}\left(\mathrm{NH}^{+}\right)$at $8.81 \pm 0.08$. For compound 4, potentiometric measurements (Figure 11) and fitting of the data using the STOICHIO program ${ }^{23,24}$ revealed values for $\mathrm{pK}_{\mathrm{a} 1}(\mathrm{OH})$ of $3.36 \pm 0.13$ and $\mathrm{pK}_{\mathrm{a} 2}\left(\mathrm{NH}^{+}\right)$ of $10.01 \pm 0.07 .{ }^{24}$ The pI values of compounds $\mathbf{3}$ and $\mathbf{4}$ were estimated to be 6.08 and 6.68 , respectively.

The deprotonation steps for the aminohydroxyquinones, as exemplified by compound $\mathbf{3}$, are depicted in Figure 12 showing 

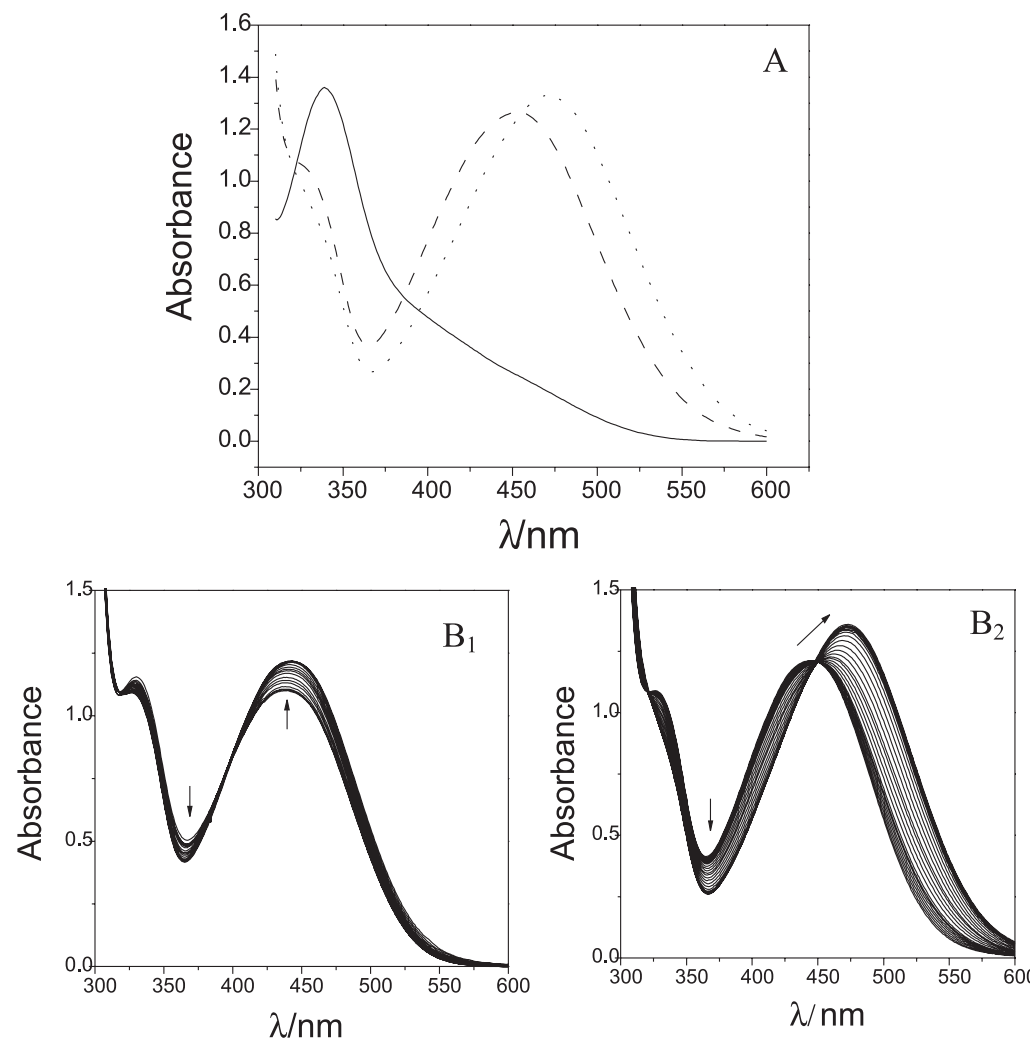

Figure 7. A) Absorption spectra of a water:ethanol (1:1) solution of 3 recorded at $\mathrm{pH}$ values $1.20(-), 6.40(--)$ and 12.00 (...). B) UV-Vis spectrophotometric titration of a water:ethanol (1:1) solution of 3 in the range $\mathrm{pH} 3.0$ to $7.7\left(\mathrm{~B}_{1}\right)$ and 7.7 to $11\left(\mathrm{~B}_{2}\right) . C_{3}=5.39 \times 10^{-4} \mathrm{~mol} \mathrm{~L}^{-1}, C_{\text {acid }}=7.46 \times 10^{-4} \mathrm{~mol} \mathrm{~L}^{-1}, C_{\text {base }}=$ $8.944 \times 10^{-3} \mathrm{~mol} \mathrm{~L}^{-1}, \mathrm{~V}_{\text {base }}=0.0041 \mathrm{~mL}$. The arrows indicate the change in absorbance ( $\downarrow$ decrease; $\uparrow$ increase) upon addition of base and the direction $(\rightarrow)$ of the bathochromic shift.
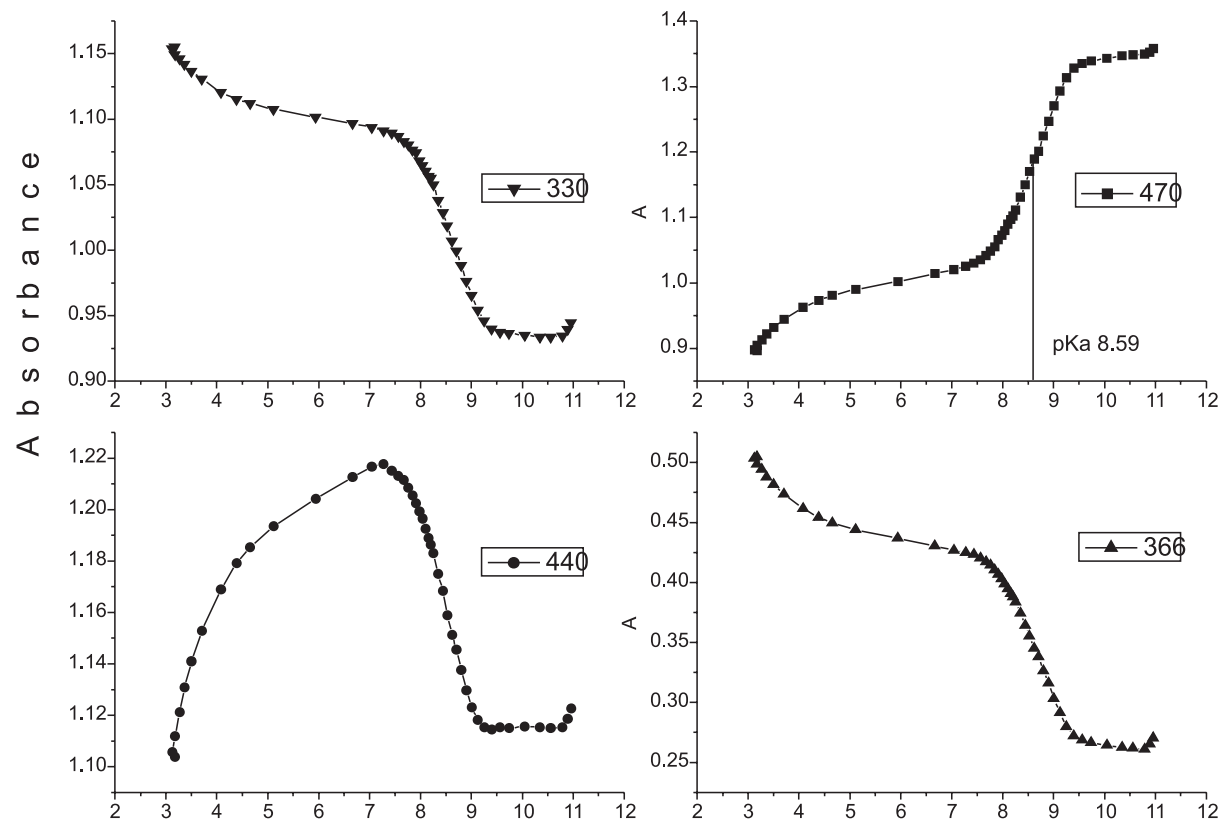

$\mathrm{pH}$

Figure 8. Absorption at different wavelengths of a water:ethanol (1:1) solution of $\mathbf{3}$ as a function of $\mathrm{pH}$. The point of inflection on the $470 \mathrm{~nm}$ plot gave a pK value of 8.59 . 


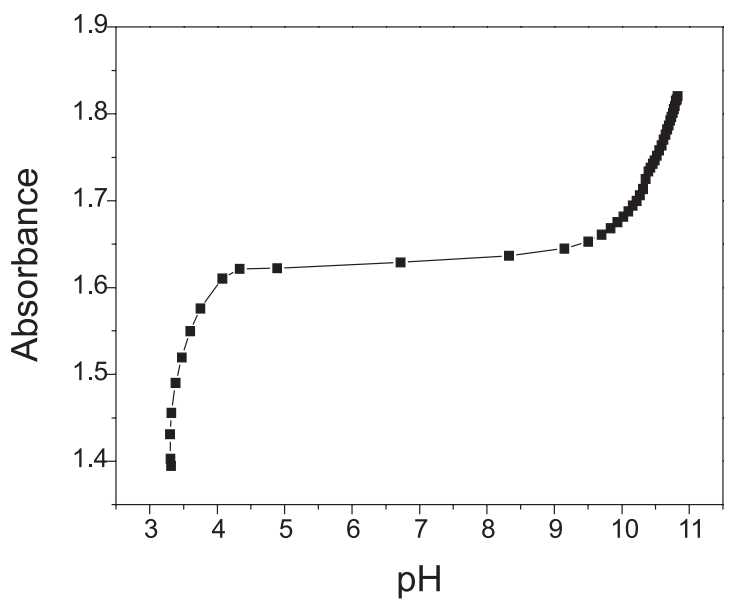

Figure 9. Absorption at $470 \mathrm{~nm}$ of a water:ethanol (1:1) solution of $\mathbf{4}$ as a function of $\mathrm{pH} . C_{4}=7.43 \times 10^{-4} \mathrm{~mol} \mathrm{~L}^{-1}$.

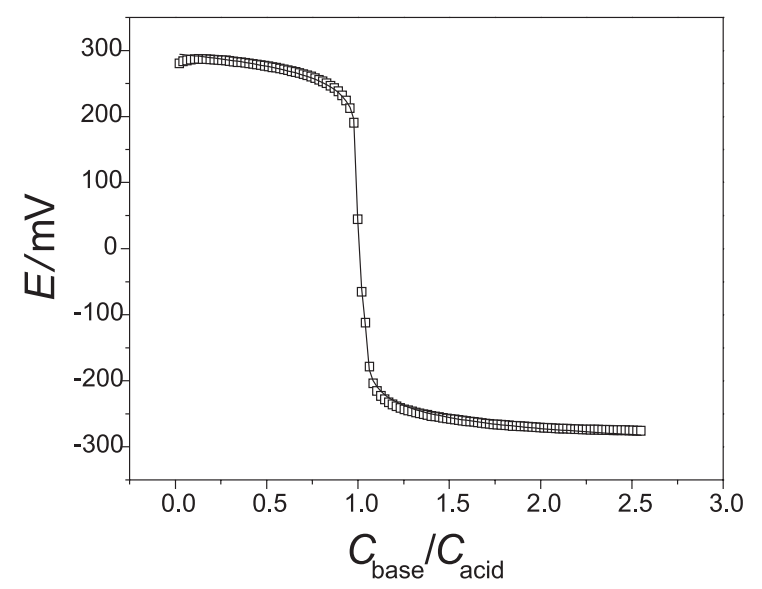

Figure 10. Potentiometric titration of a water:ethanol (1:1) solution of 3 . $C_{3}=5.12 \times 10^{-4} \mathrm{~mol} \mathrm{~L}^{-1}, C_{\text {aid }}=1.1977 \times 10^{-4} \mathrm{~mol} \mathrm{~L}^{-1}, C_{\mathrm{bes}}=1.2252 \times 10^{-1} \mathrm{~mol}$ $\mathrm{L}^{-1} ; \mathrm{pK}_{\mathrm{a} 1}$ calculated as $3.36 ; \mathrm{pK}_{\mathrm{a} 2}$ calculated as 8.81. Experimental points are represented as $\square$ whilst calculated points are shown as a solid line.

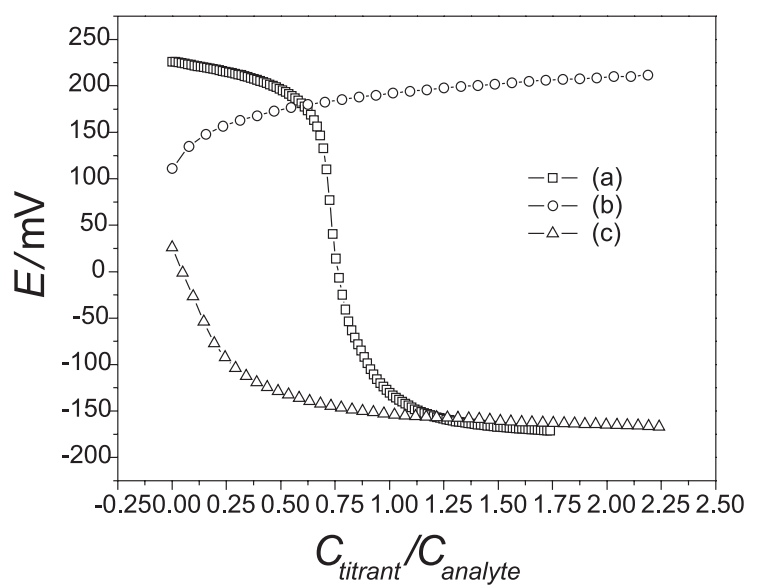

Figure 11. Potentiometric titration of a water:ethanol $(1: 1)$ solution of 4 with (a) $c_{4}=3.66 \times 10^{-4} \mathrm{~mol} \mathrm{~L}^{-1}, C_{\text {acid }}=1.23 \times 10^{-3} \mathrm{~mol} \mathrm{~L}^{-1}, C_{\text {base }}=7.20$ $\times 10^{-3} \mathrm{~mol} \mathrm{~L}^{-1}$; (b) $c_{4}=4.10 \times 10^{-4} \mathrm{~mol} \mathrm{~L}^{-1}, C_{\text {acid }}=1.16 \times 10^{-2} \mathrm{~mol} \mathrm{~L}^{-1}$; (c) $c_{4}=4.21 \times 10^{-4} \mathrm{~mol} \mathrm{~L}^{-1} ; C_{\mathrm{base}}=7.20 \times 10^{-3} \mathrm{~mol} \mathrm{~L}^{-1}$.

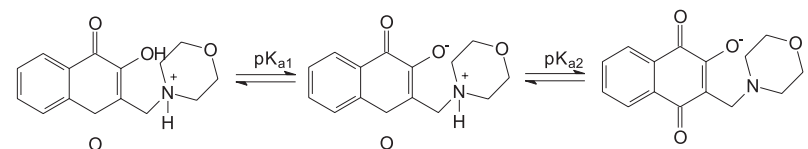

Figure 12. Deprotonation steps associated with compound 3 .

that $\mathrm{pK}_{\mathrm{a} 1}$ is related to the ionisation of the enol and that $\mathrm{pK}_{\mathrm{a} 2}$ relates to the removal of proton from the ammonium salt.

Comparison of the potentiometric and spectroscopic data for compounds 1-4 lead to the conclusion that the proposed equilibrium models were valid and generate the expected values for $\mathrm{pK}_{\mathrm{a} 1}$ and $\mathrm{pK}_{\mathrm{a} 2}$. Generally, the potentiometric method gave more precise $\mathrm{pK}_{\mathrm{a}}$ values than the spectrometric method, and could also be employed over a broader range of $\mathrm{pK}$. The main disadvantage of the method relates to the difficulty in finding suitable models for the equilibria.

The profiles of the distributions of base $\left(\mathrm{AO}^{-}\right)$, neutral $(\mathrm{AOH})$ and acidic $\left(\mathrm{AOH}_{2}^{+}\right)$species of compounds 1-4 are shown in Figure 13. In terms of $\mathrm{pK}_{\mathrm{a} 1}$ the order of acidity is $\mathbf{3}=\mathbf{4}>\mathbf{2}>\mathbf{1}$, and an enolate ion is generated in all cases. For compounds $\mathbf{3}$ and $\mathbf{4}$, intramolecular hydrogen bonding
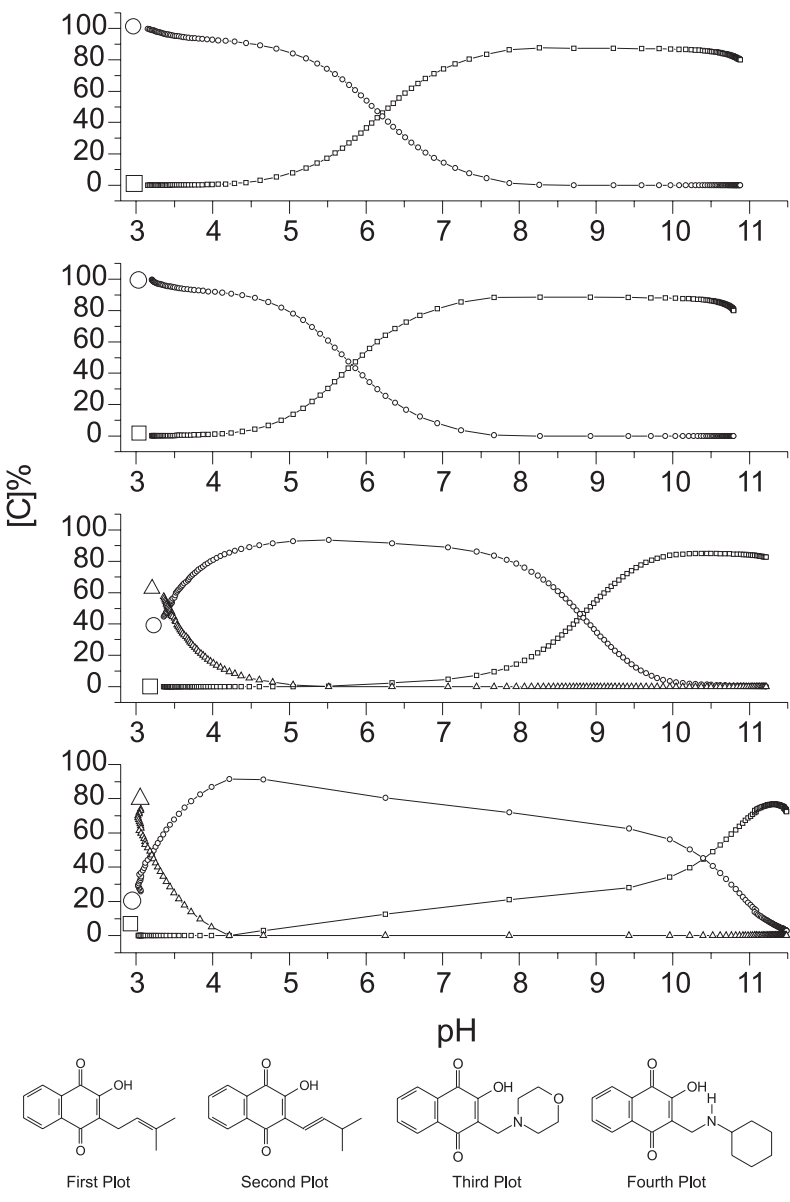

Figure 13. Profiles of the distributions of base ( $\left.\mathrm{AO}^{-} ; \square\right)$, neutral ( $\mathrm{AOH}$; $\mathrm{O})$, and acidic $\left(\mathrm{AOH}_{2}^{+} ; \Delta\right)$ species of compounds 1-4. 
<smiles>O=C1C(O)=C(C[N+](CO)(CO)C2CCCCC2)C(=O)c2ccccc21</smiles>

A

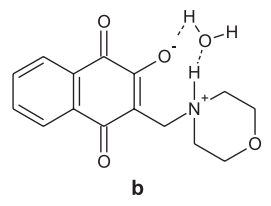

B

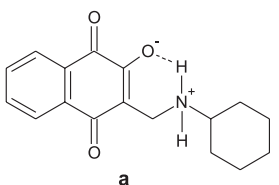

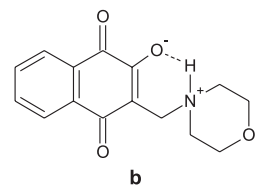

Figure 14. A) Possible hydrogen-bonding interactions between solvent and the enolate ion of (a) compound 4, and (b) compound 3. B) Stabilization by intramolecular hydrogen bonding of the enolate ion of (a) compound $\mathbf{4}$, and (b) compound $\mathbf{3}$.

explains the higher acidity of these quinones (Figure 14B), whilst for isolapachol (2), the extension of conjugation to the double bond of the substituent explains its higher acidity in comparison with $\mathbf{1}$.

Generally, the variation in basicity of the aliphatic amines (primary, secondary and tertiary) is associated with stereoelectronic and solvation effects of their conjugate acids. For compounds $\mathbf{3}$ and $\mathbf{4}$, the differences in $\mathrm{pK}_{\mathrm{a} 2}$ must be related to solution ${ }^{27}$ and substituent electronwithdrawing effects, the latter referring to the morpholine group of 3. Solvation through hydrogen bonding tends to increase the apparent strength of all amines, since a positively charged ammonium ion is more effectively solvated than an uncharged amine. In comparison with $\mathbf{3}$, the extent of solvation of the ammonium salt of $\mathbf{4}$ is enhanced since increased hydrogen bonding stabilizes the conjugate acid (Figure 14A) and consequently leads to a higher $\mathrm{pK}_{\mathrm{a} 2}$ value. ${ }^{27}$

In terms of biological properties, compounds $\mathbf{1}$ and $\mathbf{2}$ exhibit a broad spectrum of activities, whilst $\mathbf{3}$ and $\mathbf{4}$, as representatives of a class of fourteen 2-hydroxy-3methylnitrogenated-1,4-naphthoquinones, are inactive in various biological assays (Table 1).

The great majority of drugs are passively absorbed and need to cross the lipid bilayers that constitute the hydrophobic environment of biological membranes. Whether a drug is able to attain plasmatic concentrations sufficient to produce biological or pharmacological effects depends to a great extent on the lipophilicity and $\mathrm{pK}_{\mathrm{a}}$ of the compound. ${ }^{14-16}$ In this context, the hydrophobic nature of a molecule is fundamental to the facilitation of its transport across cell membranes and can be important in its interactions with receptors. ${ }^{16} \mathrm{~A}$ zwitterionic species possesses a large intramolecular multipole moment owing to its multiplicity of oppositely charged groups. ${ }^{28}$ Consequently, most zwitterionic compounds exhibit low solubility in polar and non-polar media, and this results in low membrane permeability. ${ }^{29} \mathrm{As}$ measured in the present study, the pI values of $\mathbf{3}$ and $\mathbf{4}$ (6.08 and 6.68, respectively) indicate a strong contribution of the zwitterionic forms of these molecules at physiological $\mathrm{pH}$ values, and this could be the reason for their lack of biological activity. However, organisms possess various mechanisms that can circumvent such problems of transportation involving, for example, ion-pairing or the participation of L-carnitine. Hence, in order to obtain unequivocal proof of the inactivity of the methylaminohydroxyquinones, in vivo or in situ assays need to be carried out. ${ }^{29,30}$

\section{Conclusions}

At physiological $\mathrm{pH}$, isolapachol (2) is more acidic than lapachol (1), and the biologically inactive methylaminohydroxyquinones $\mathbf{3}$ and $\mathbf{4}$ are, to a large extent, zwitterionic. In all four compounds, the first $\mathrm{pK}_{\mathrm{a}}$ is related to the ionisation of the enol, and the differences in acidity of the-OH group may be explained in terms of the stabilisation of the enolate ion by hydrogen bonding. Compound $\mathbf{3}$ has a tertiary amino functional group, the conjugate acid of which is stronger than the acid derived from the secondary amine present in $\mathbf{4}$. The results obtained can be considered as starting points in the understanding of the mechanism of biological activity, however, additional work is needed in order to determine whether these parameters are relevant under physiological conditions and in vivo.

\section{Acknowledgments}

The authors wish to thank Prof. Antonio Ventura Pinto (Núcleo de Pesquisas de Produtos Naturais, Universidade Federal do Rio de Janeiro, Brazil) for the kind gift of quinones 1, 3 and 4. Financial support by the Brazilian agencies MCT/CNPq, CAPES/COFECUB, PADCT/CNPq, FAPEAL, BNB, IM-INOFAR (Instituto do Milênio-Inovação em Fármacos), CNPq/MS/Neoplasias and RENORBIO is greatly acknowledged.

\section{References}

1. Subramanian, S.; Ferreira, M. M. C.; Trsic, M.; Struct. Chem. 1998, 9, 47.

2. dos Santos, A. F.; Ferraz, P. A. L.; Abreu, F. C.; Chiari, E.; Goulart, M. O. F.; Sant'Ana, A. E. G.; Planta Med. 2001, 67, 92.

3. dos Santos, A. F.; Ferraz, P. A. L.; Pinto, A. V.; Pinto, M. C. R. F.; Goulart, M. O. F.; Sant'Ana, A. E. G.; Int. J. Parasitol. 2000, 30, 1199 . 
4. Lima, N. M. F.; dos Santos, A. F.; Porfírio, Z.; Goulart, M. O. F.; Sant'Ana, A. E. G.; Acta Trop. 2002, 83, 43.

5. Goulart, M. O. F.; Zani, C. L.; Tonholo, J.; Abreu, F. C.; Raslan, D. S.; Starling, S.; Oliveira, A. B.; Chiari, E.; Bioorg. Med. Chem. Lett. 1997, 7, 2043.

6. Goulart, M. O. F.; Sant'Ana, A. E. G.; Lima, N. M. F.; Leon, L. L.; Mem. Inst. Oswaldo Cruz, 2004, 99, 757.

7. Lima, N. M. F.; Correia, C. S.; Ferraz, P. A. L.; Pinto, A. V.; Pinto, M. C. R. F.; Sant'Ana, A. E. G.; Goulart, M. O. F.; J. Braz. Chem. Soc. 2002, 13, 822.

8. Chitsulo, L.; Engels, D.; Montresor, A.; Savioli, L.; Acta Trop. 2000, 77, 41 .

9. Perrett, S.; Whitfield, P. J.; Parasitol. Today 1996, 12, 156.

10. Lima, N. M. F.; Ph.D. Thesis, Universidade Federal de Alagoas, 2004.

11. Oliveira, M. F.; Lemos, T. L. G.; Mattos M. C.; Segundo, T. A.; Santiago, G. M. P.; Braz-Filho, R.; An. Acad. Bras. Cienc. 2002, 74, 211.

12. Bishop, C. A.; Tong, L. K. J.; J. Am. Chem. Soc. 1965, 87, 501.

13 Van de Waterbeemd, H.; Gifford, E.; Nat. Rev. Drug Discovery 2003, 2, 192.

14. Van de Waterbeemd, H.; Lennernäs, H.; Artursson, P.; Drug Bioavailability, Wiley: Weinheim, 2004.

15. Kunz, K. R.; Iyengar, B. S.; Dorr, R. T.; Alberts, D. S.; Remers, W. A.; J. Med. Chem. 1991, 34, 2281.

16. Patrick, G. L.; Introduction to Medicinal Chemistry, Oxford University Press: New York, 1995.

17. Avdeef, A.; Box, K. J.; Comer, J. E. A.; Gilges, M.; Hadley, M.; Hibbert, C.; Patterson, W.; Tam, K. Y.; J. Pharm. Biomed. Anal. 1999, 20, 631.
18. Ferreira, V. F.; Pinto, A. V.; Pinto, M. C. F. R.; Cruz, M. C.; Clarino, A.; Synthetic Commun. 1989, 19, 1061.

19. Leffler, M. T.; Hathaway, R. J.; J. Am. Chem. Soc. 1948, 70, 3222.

20. Bruck, R. P.; Rondinini, S. R.; Covington, A. K.; Baucke, F. G. K.; Barett, C. M. A.; Camoes, M. F.; Milton, M. J. T.; Mussini, T.; Naumann, R.; Paratt, K. W.; Spitzer, P.; Wilson, G. S.; Pure Appl. Chem. 2002, 74, 2169.

21. Mussini, P. R.; Mussini, T.; Rondinini, S.; Pure Appl. Chem. 1997, 69, 1007.

22. Rondinini, S.; Longhi, P.; Mussini, P. R.; Mussini, T.; Pure Appl. Chem. 1987, 59, 1693.

23. Kostrowicki, J.; Liwo, A.; Talanta 1990, 37, 645.

24. Bogdanska, A.; Chmurzynski, L.; Ossowski, T.; Liwo, A.; Jeziorek, D.; Anal. Chim. Acta 1999, 402, 339.

25. Albert, A.; Briggs, J. M.; The Determination of Ionisable Constants, Chapman and Hall: London, 1971.

26. Perrin, D. D.; Dempsey, B.; Buffers for $\mathrm{pH}$ and Metal Ion Control, Wiley: New York, 1974.

27. Huheey, J. E.; Keiter, E. A.; Keiter, R. L.; Inorganic Chemistry, $4^{\text {th }}$ ed., Harper Collins: New York, 1993, pp. 343-344.

28. Cheong, H-A.; Choi, H-K.; Pharm. Res. 2002, 19, 1375.

29. Hatanaka, T.; Kamon, T.; Morigaki, S.; Katayama, K.; Koizumi, T.; J. Controlled Release 2000, 66, 63.

30. Hirano, T.; Yasuda, S.; Osaka, Y.; Kobayashi, M.; Itagaki, S.; Iseki, K.; Biochim. Biophys. Acta 2006, 1758, 1743.

Received: February 28, 2007 Published on the web: January 30, 2008 